\title{
Article
}

\section{Local community perceptions of disaster tourism: the case of L'Aquila, Italy}

Wright, D., and Sharpley, R.

Available at http://clok.uclan.ac.uk/14518/

Wright, D., ORCID: 0000-0001-9976-5799 and Sharpley, R. ORCID: 0000-00022135-3206 (2016) Local community perceptions of disaster tourism: the case of L'Aquila, Italy. Current Issues in Tourism, 21 (14). pp. 1569-1585. ISSN $1368-3500$

It is advisable to refer to the publisher's version if you intend to cite from the work. http://dx.doi.org/10.1080/13683500.2016.1157141

For more information about UCLan's research in this area go to

http://www.uclan.ac.uk/researchgroups/ and search for < name of research Group>.

For information about Research generally at UCLan please go to http://www.uclan.ac.uk/research/

All outputs in CLoK are protected by Intellectual Property Rights law, including Copyright law. Copyright, IPR and Moral Rights for the works on this site are retained by the individual authors and/or other copyright owners. Terms and conditions for use of this material are defined in the policies page.

\section{CLoK}

Central Lancashire online Knowledge www.clok.uclan.ac.uk

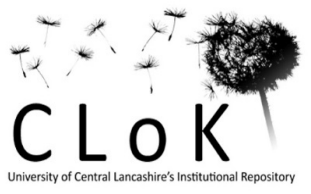


Local community perceptions of disaster tourism: the case of L'Aquila, Italy

\begin{abstract}
Despite increasing research in dark tourism, few attempts have been made to explore local community perceptions of becoming the object of the dark tourist gaze, an issue that is of particular relevance at disaster sites given the potential sensitivity of local people to the intrusion of tourists in the aftermath of a disaster. This paper addresses this significant gap in the literature. Based on research undertaken in L'Aquila, an Italian city that in April 2009 suffered a devastating earthquake, it explores the responses of members of the local community to their city becoming a dark (disaster) tourism destination. In so doing, it reveals an evolving response towards tourism that not only contradicts traditional understandings of resident perceptions of tourism, but also points towards how appropriate responses to disaster tourism might support the disaster recovery process.
\end{abstract}

Key words: dark tourism; disaster tourism; community; host perceptions; L'Aquila

\title{
1. Introduction
}

Visiting places and events associated with death, suffering and tragedy is not new (Cohen, 2011; Westover, 2012), early forms of such tourism including medieval pilgrimages or travel to attend public executions. According to Seaton (1996), the relationship between death and tourism, or 'thanatourism', intensified from the nineteenth century onwards, but it is only more recently that so-called 'dark tourism' has become the focus of increasing academic attention (Biran \& Hyde, 2013; Sharpley \& Stone, 2009; Stone, 2013).

However, research into dark tourism pre-dates the coining of the term. Uzell (1989), for example, argued for the 'hot' interpretation of war and conflict sites as a means of enhancing visitors' understanding of the events that occurred, whilst Tunbridge and Ashworth's (1996) work on 'dissonant heritage' established an important framework for the subsequent consideration of dark heritage sites (Muzaini, Teo \& Yeoh, 2007). In particular, Rojek (1993) introduced the notion of dark attractions or what he termed 'Black Spots'. Referring to them as postmodern spectacles, he typified them as the 'commercial development of grave sites and sites in which celebrities or large numbers of people have met with sudden and violent death' (Rojek, 1993, p 136). Significantly, he later distinguished between these and sites of disasters that also attract tourists, describing the latter as 'analytically distinct from Black Spots as sensation sites' (Rojek, 1997, p. 63). A similar distinction is made by Blom (2000) who compared 'morbid tourism' that 'focuses on sudden 
death and which quickly attracts large numbers of people' with 'artificial morbidity-related tourism' to existing 'dark' attractions.

Importantly, both Rojek and Blom thus established a dichotomy that has since persisted in the academic study of dark tourism. In other words, attention in the literature has typically and predominantly been paid to the definition, categorisation and theoretical analysis of dark tourism attractions; that is, to places associated with recent or historical death and suffering that intentionally or otherwise attract tourists on a regular basis. Conversely, disaster tourism sites, or places where disasters occur and immediately but often only temporarily attract a significant number of tourists (those who come to view the outcomes of the disaster rather than working as 'volunteer tourists' in disaster recovery), have with a few notable exceptions (for example, Coats \& Ferguson, 2013; Gould \& Lewis, 2007) been overlooked in the literature. More specifically, few if any attempts have been made to consider the perceptions of local people to becoming the object of the dark tourist gaze in the aftermath of a disaster, a surprising omission given the immediacy and potential impacts of tourism on the local community and the recovery process in places where disasters have recently occurred.

The purpose of this paper is to address this gap in the literature. Based on a case study of L'Aquila, a city in Italy that in 2009 suffered a severe earthquake, it discusses the outcomes of research into the perceptions of the local residents to their city becoming a disaster tourism attraction and how those perceptions transformed over time. In so doing, it seeks not only to add a new dimension to the dark tourism literature in general but also to identify how disaster tourism might be better managed to contribute to the disaster recovery process in particular. Fundamental to the paper is an understanding of what a disaster 'is', particularly from the perspective of those who have suffered a disaster. Hence, the first task is to conceptualise briefly disaster sites as dark tourism destinations.

\section{Disasters as (dark) tourism attractions}

As Barkun (1974, p. 51) observes, '... a disaster is perhaps easier to recognise than it is to define'. Within the tourism literature, attempts to define disasters have typically been undertaken within the context of crisis and disaster management (Pforr \& Hosie, 2007), the focus primarily being on distinguishing between a crisis and a disaster. Consensus over definitions of the two terms has yet to emerge (Santana, 2004) although typically, the former is considered to be an event that is 'to some extent, self-inflicted (Faulkner, 2001, p. 136). A disaster, conversely, is considered to be an external, unpredictable and uncontrollable event. 
Others, however, argue that it is not an actual event but the extent of society's vulnerability to it that determines or defines a disaster (Smith, 1995; Twigg, 2004).

Nevertheless, these debates do not address the essence of a disaster. Numerous definitions are offered in the academic and professional literature, although UNIDSR (2009, p. 9) captures the fundamental characteristics of a disaster as being 'A serious disruption of the functioning of a community or a society involving widespread human, material, economic or environmental losses and impacts, which exceeds the ability of the affected community or society to cope using its own resources.' In other words, a disaster can be summarised as an extraordinary event, recovery from which demands external assistance and resources (Tierney, Lindell \& Perry, 2001). However, such a 'serious disruption' may be defined from alternative disciplinary, theoretical or practical perspectives. For example, von Vacano and Zaumseil (2013) cite definitions of disaster rooted in sociology, geography, anthropology and psychology whilst Quarantelli (1985) identifies seven conceptual perspectives on studying disasters commonly adopted in the literature

Irrespective of these broad perspectives on what a disaster is, however, in the context of this paper it is the consequences of a sudden, unpredictable and extreme event that define it not only as a disaster but also as a (dark) tourism attraction. More specifically, it is arguably the human cost of an 'event concentrated in time and space, in which a society or one of its subdivisions undergoes physical harm and social disruption' (Kreps, 1995, p. 256), often measured in a relatively significant number of deaths and injuries, that transforms the site of a disaster into a disaster tourism destination - or at least into a potential destination, for not all disaster sites are immediately accessible to tourists. Putting it another way, dark tourism is typically defined as 'visitation to places where tragedies or historically noteworthy death has occurred' (Tarlow, 2005, p. 48) or, more generally, 'the act of travel to sites associated with death, suffering and the seemingly macabre' (Stone, 2006, p. 146). Hence, it is the fact that a disaster results in a significant number of fatalities and consequently attracts tourists, for whatever reason, to the site where it has occurred that justifies its categorisation under the heading of dark tourism.

It is beyond the scope of this paper to review the concept of dark tourism more generally (see for example Biran \& Poria, 2012; Bowman \& Pezzullo, 2009; Stone, 2013). Nevertheless, it is important to note that although disaster tourism is widely considered to be a sub-set of dark tourism, it is indeed 'analytically distinct' (Rojek, 1997: 63) from it, in four key respects. 
First, disaster tourism sites are typically only temporary, in as much as they attract 'disaster tourists' (to gaze upon the consequences of the disaster) only for as long as those consequences are in evidence. For example, once damaged buildings have been demolished and reconstruction has begun (or, as occurred in 2014, the wreck of the SS Costa Concordia was finally salvaged and removed from Isola del Giglio off the coast of Italy two years after it sank), a site can no longer be conceptualised as a disaster tourism destination.

Nevertheless, it may evolve into a dark tourism destination should it subsequently become a place of pilgrimage or commemoration (Logan \& Kier Reeves, 2008; White \& Frew, 2013). Thus, some disaster sites may be thought of as nascent dark tourism attractions as defined in the literature.

Second, disaster sites are, in a tourism context, often unmanaged or 'raw' sites. That is, there may be limited or no tourism services or infrastructure, although this is not always the case. For example, according to Gould \& Lewis (2007), an 'eco-disaster tourism industry' was quick to emerge in New Orleans following hurricane Katrina in 2005. Similarly, commercially operated Red Zone bus tours were established in Christchurch, New Zealand following the earthquake that devastated the city in 2011 (Coats \& Ferguson, 2013). However, it is often the case that people will spontaneously visit and experience disaster sites as tourists without the benefit of organised tours, official guidance and interpretation and so on. That is, disaster tourism may occur independently from any formal tourism sector involvement.

Third, tourists visit dark sites for a wide variety of purposes (Raine, 2013). Furthermore, given the potential for dark tourism sites to mediate between visitors and the event (and death) represented, commemorated or interpreted by the site (Stone, 2012), the assumption that tourism to dark sites is driven by a morbid fascination in death has been increasingly challenged, to the extent that it is considered not only pejorative but erroneous to refer to the 'dark tourist' (Bowman \& Pezzullo, 2009). In the case of tourist visits to disaster sites, however, it would be difficult to deny that such tourism is to some extent 'morbid' (Blom, 2000) or defined by at least an element of fascination, voyeurism or schadenfreude.

Finally, disaster tourism is distinctive from dark tourism more generally inasmuch as the local community often becomes the focus of the 'disaster tourist' gaze. In other words, a disaster as commonly defined is manifested in its social consequences or, as Fritz (1961, p. $655)$ puts it, in 'an event... in which a society... undergoes severe danger and incurs such losses to its members and physical appurtenances that the social structure is disrupted and the fulfilment of all or some of the essential functions of the society is prevented'. Thus, it is that 
disrupted society, the victims, survivors or bystanders of the event that tourists come to gaze upon. Therefore, if disaster tourism and its consequences for a community are to be managed effectively, then it is necessary to understand the perceptions and responses of the community to becoming, in effect, a tourism attraction.

\section{Local community perceptions of tourism}

The perceptions and attitudes of the local community (or residents / hosts) in established or potential tourist destinations have long been the focus of academic scrutiny. Based upon the premise that the successful and sustainable development of tourism is dependent upon the goodwill of the destination community (Jurowski \& Gursoy, 2004; Pérez \& Nadal, 2005), numerous studies have sought to identify the attitudes and perceptions of the local community to the consequences of tourism development in order to guide or inform so-called 'resident responsive' tourism planning (Vargas-Sánchez, Plaza-Mejía \& Porras-Bueno, 2009). Consequently, 'research on resident attitudes of tourism... [has become] ... one of the most systematic and well-studied areas of tourism' (McGehee \& Anderek 2004, p. 132). Nevertheless, recent reviews question the extent to which a deeper, more nuanced and theoretically robust understanding of local communities' perceptions of tourism has emerged from the research (Deery, Jago \& Fredline, 2012; Nunkoo, Smith \& Ramkissoon, 2013; Sharpley, 2014).

Certainly, initial work revealed a typically descriptive approach (Ap, 1990), although the research has subsequently developed in terms of scope, theoretical underpinning and conceptual design (Deery et al., 2012: Harrill, 2004); whereas early studies focused on 'tourism impact' (McGehee \& Anderek, 2004, p. 132), exploring the extent to which documented social, economic and environmental impacts of tourism are perceived by the destination community, as well as proposing well-known though simplistic models of residents' responses to tourism development (Butler, 1980; Doxey, 1975), more recent work adopted a 'tourism perceptions' approach (McGehee \& Anderek, 2004, p. 132). This, on the one hand, identifies and tests a variety of variables, both intrinsic and extrinsic, that may determine or predict residents' perceptions of tourism (Faulkner \& Tideswell, 1997) and, on the other hand, segments local communities according to their degree of support for tourism (Andriotis \& Vaughan, 2003; Pérez \& Nadal, 2005). Most recently, research has explored tourism within the broader context of residents' quality of life / well-being (Andereck \& Nyaupane, 2011; Kim, Uysal \& Sirgy 2013), whilst attempts have also been made to locate 
the research within theoretical frameworks, notably social action theory, albeit unconvincingly (Pearce, Moscardo \& Ross, 1996).

Despite this progress, however, the research continues to suffer a number of limitations, not least the adoption of a 'one-off', case study-based approach in untypical tourism locations (Nunkoo \& Gursoy, 2012) focusing on specific, pre-determined sets of variables, thereby limiting the validity and generalisability of outcomes (Huh \& Vogt, 2008). At the same time, much work focuses on perceptions of rather than responses to tourism, a notable exception being Carmichael's (2000) study of local residents' responses to a casino development, whilst research into residents' perceptions of and interactions with tourists themselves is curiously rare. Of most significance, however, the great majority of studies employ quantitative methods, enhancing what some commentators consider to be the simplistic and theoretically weak character of much of the research (Woosnam, 2012). That is, 'perception studies tend to reduce the reality of the ...[host]... gaze to what is visible; yet we know what is visible is not the whole truth' (Moufakkir \& Reisinger, 2013, p. xiii). What is lacking is knowledge and understanding of the wider social reality of individual residents' lives and of the local community more generally and how this influences perceptions of tourism in particular. Hence, there have been calls for multi-dimensional, qualitative studies that, in general, have the potential to explain not only how but why the local community perceive and respond to tourism (Deery et al., 2012; Sharpley, 2014). More specifically, in complex and potentially sensitive contexts, including disaster tourism sites, the 'whole truth' of the local community's perceptions of tourism is likely to be revealed only through a deeper, more nuanced understanding of their social reality. Indeed, as the research now discussed in this paper demonstrates, distinctions and transformations in perceptions of tourism and tourists amongst members of the local community following the earthquake in L'Aquila reflect both L'Aquilan culture in general and the disaster recovery process in particular.

\section{The research: Disaster Tourism in L'Aquila}

\subsection{Study Context}

L'Aquila (in English, The Eagle), a city of some 68,000 inhabitants, is located in and capital of the Abruzzo region in central Italy. Lying in a valley $720 \mathrm{~m}$ above sea level, it is surrounded by four Apennine peaks of over $2000 \mathrm{~m}$ and although only $100 \mathrm{~km}$ from Rome, as a consequence remains relatively remote. Dating back to the $13^{\text {th }}$ Century, its long and varied history as a significant political and economic centre is reflected in its wealth of Baroque and 
Renaissance buildings. In modern times, however, it is best known as a cultural centre, home to the University of L'Aquila and, as a tourism destination, a base for primarily domestic summer and winter mountain activities such as hiking and skiing.

On $6^{\text {th }}$ April 2009, L'Aquila was struck by a major earthquake. Measuring 5.8 on the Richter scale, it destroyed or damaged much of the city's historical centre; 309 people lost their lives, a further 1,500 were injured and the majority of the population was made homeless. This was by no means the first earthquake in L'Aquila, a significant number having been recorded throughout its history and the most serious occurring in 1786 with the loss of more than 6,000 lives. Nevertheless, the 2009 earthquake was unique in two respects. First, it was a national Italian disaster rather than a L'Aquilan disaster inasmuch as, unlike previous earthquakes, national resources and support was provided (at least, initially) to aid recovery. And second, the city immediately became a disaster tourism destination. Observers at the time noted an influx of tourists, Flamminio (2009) for example observing that whilst the ex-inhabitants of L'Aquila were living in tents, tourists were attempting to enter the old town (at that time only open to disaster response teams) in order to take pictures and to collect souvenirs. Similarly, some six months after the earthquake, an article (InAbruzzo, 2009) titled Il terremoto diventa attrattore turistico (trans. 'The earthquake becomes a tourist attraction') suggested that the earthquake had achieved what the regional tourism authorities long failed to do. That is, during the summer months the city had, for the first time, become a popular tourist destination, although visitors came not see L'Aquila's cultural wealth; rather they were attrati dal'lorrore della città distrutta, ('attracted to the horror of the destroyed city').

Significantly, the subsequent disaster recovery process in L'Aquila has been both slow and controversial. In the immediate aftermath of the earthquake aid was sent to L'Aquila from around the world (Williams, 2009), construction of temporary housing was undertaken (Alexander, 2010), a variety of measures were put in place to provide financial support and security for the local population (Rossi et al., 2012) and plans were put in place for the reconstruction of the city. However, two years after the disaster, little progress had been made in rebuilding the damaged areas of the city. Reconstruction was seen to be hindered by inefficiency, excessive bureaucracy, broken promises and corruption and, consequently, many local people felt that, having been victims of the original disaster they were now victims of a failing recovery process (Di Nicola, 2011). Four years after the earthquake, reconstruction had come to a virtual standstill; much of the historic centre remained in ruins, 22,000 residents were still living in temporary accommodation and, 
according to Dinmore (2013), L'Aquila had 'become a monument to Italy's economic and political paralysis'. Hence, the research into the local community's perceptions of disaster tourism in L'Aquila was undertaken against the background of not only the immediate and significant physical and human cost of the earthquake but also a growing sense amongst the population that their disaster had been forgotten by the outside world.

\subsection{Study Methods}

For the purposes of this research, and in response to the limitations of quantitative, surveybased studies of resident perceptions of tourism discussed earlier in this paper, semistructured interviews were adopted as the most appropriate methodology. More specifically, semi-structured interviews were selected as a means of, on the one hand, eliciting deep, rich and meaningful data within 'multi-layered accounts of respondent experiences' (Sandiford \& Seymour, 2007, p. 724) and, on the other hand, ensuring that the objectives of the research were addressed throughout the interviews. Moreover, given the complex, emotive and potentially difficult issues to be considered, semi-structured interviews offered the flexibility of allowing discussions to evolve around and follow respondents' personal reflections on the disaster, the disaster-recovery process and, specifically, disaster tourism within the framework of those research objectives (Gillham, 2005).

The interviews were undertaken during a three-month period in the summer of 2012 during which the first author of this paper, who is bilingual in Italian and English, was based in the Abruzzo region. A total of 34 respondents were interviewed, many of whom had lived in L'Aquila for most, if not all of their lives. However, some more recent residents, such as students, also participated. An equal number of men and women were interviewed, varying in age from 20 to 77 but relatively evenly spread across age ranges and representing a variety of occupations, such as teachers, students, social workers, photo-journalists, engineers and tourism / hospitality professionals. A deputy mayor and a priest also participated in the interviews. Respondents were selected through a form of snowballing built on existing contacts in the city. This was adopted as the most appropriate sampling method for a number of reasons. First, the displacement of much of the population to surrounding villages and towns following the earthquake significantly complicated the process of identifying and accessing appropriate respondents; second, the research required respondents who would be able to talk openly about difficult and sometimes painful topics; and third, it was evident that the local community had become suspicious of journalists and other 'outsiders' wanting to talk about the earthquake and its aftermath. Hence, a process of recommendation and 
introduction was deemed the most effective in securing a representative sample of respondents willing and able to participate in the research.

The interviews, each lasting between 45 minutes and 1 hour and 30 minutes, took place in a variety of locations in and around L'Aquila either in respondents' homes or in a local café or bar. The discussions covered a variety of themes relevant to the research objectives but sought specifically to address two broad areas of concern, namely: the social reality of respondents as members of the local community of L'Aquila who had experienced and survived the earthquake of April 2009 and were subsequently rebuilding their lives; and, their consequential perceptions of and responses to their city (and themselves) becoming a disaster tourism attraction. All interviews, conducted in Italian, were recorded and subsequently translated into English at the transcription stage, a sample of recordings / transcripts being checked by an Italian-English linguist for accuracy of translation. The data were then manually coded and subjected to thematic analysis (King and Horrocks, 2010).

\section{Research outcomes}

As noted above, the semi-structured interviews sought to elicit not only the local community's perceptions and responses to the post-earthquake emergence of disaster tourism in L'Aquila, but also to locate those perceptions and responses within an understanding of respondents' reflections on the disaster and the disaster recovery process and, indeed, on their unaccustomed role as 'hosts' to disaster tourists. Consequently, the interviews typically commenced with respondents discussing L'Aquila in general and their experiences of the earthquake in particular before focusing more explicitly on disaster tourism. A number of clear themes emerged from the research.

\section{L'Aquila: a collective social identity?}

In order to explore the perceived social identity of the people of L'Aquila and, specifically, their attitudes towards tourists and outsiders more generally, respondents were asked how they might best describe the 'Aquilani' to someone who does not know the city and its people. Given the location of the city, its historical isolation and its evident ability to recover from repeated natural disasters, what perhaps unsurprisingly emerged from the interviews was a picture of a resilient, self-supportive yet somewhat introspective society that is resistant to change and reserved towards, if not suspicious of, outsiders. As summarised by one respondent: 
Well, an Aquilano is a man who relates closely with his own city, his territory, his land; a man who is very much bound to his origins and traditions in the way he lives. He is also a little suspicious at first of others, of outsiders... However... he is a man who eventually opens his heart to you. He then gives you his trust... and eventually his friendship.

As discussed shortly, this reserved or closed character of L'Aquilan society explains, at least in part, the initially negative attitudes of the local community towards the tourists who came to the city in the immediate aftermath of the earthquake, as well as the evident lack of any formal response on the part of the city to meet their needs or exploit, for whatever purpose, the opportunities offered by their presence. With regards to further understanding the postearthquake social reality of the local community, however, the research revealed the extent to which their resilience and independence had been challenged by the disaster and ineffective recovery process, with significant implications for their subsequent responses to tourism and tourists in the city.

\section{Experiencing the earthquake and beyond}

Typically, interviews commenced with respondents being invited to recall the night of the earthquake in 2009. Many related personal and emotional stories, recalling in detail (more than three years later) the precise time the earthquake struck, the physical sensation they experienced and, in particular, the sound of the earthquake followed by the cries of victims. Implicit in many accounts was the sense that, for the people of L'Aquila, life had irrevocably changed:

The major loss to my family and me was our home. I was able to get some of my things, but the rest is still there. But the personal damage... well, I lost me, I lost who I was in there, because in reality I left that house a completely new person. The person I am now is not the same person who went to bed that evening before the earthquake.

Or, as one older respondent remarked:

My life has completely changed since the earthquake. I no longer have my house, I live with my daughter. I don't have a life; I cannot see my friends because I am old and I cannot move around on my own. 
Of greater relevance to the research, however, were the attitudes of the local community to the lack of progress, even three years after the earthquake, in rebuilding their city. Many were critical of the response of both regional and national government, the evident lack of leadership, planning and investment, and the ineffective or inappropriate allocation of financial resources: 'there isn't any money, because the money has been spent wrongly. It's pointless; if there isn't any money to help develop the city, then it will never get going again.' They also perceived that not only had they been forgotten by the outside world, but that the media were presenting a false image of L'Aquila's recovery:

It's how we are presented to the outside world by the media. I have friends in other parts of Italy that I speak with and they tell me that they hear that everything in L'Aquila is now ok. And I say 'no', you come here and have a look, then tell me if you think everything is ok.

Nevertheless, some respondents were more pragmatic, revealing the inherent resilience of people of L'Aquila:

We need to start again, from the beginning. We need to stop basking in our pain and losses. We have to see the glass half full and not the glass half empty, otherwise it will always remain half empty. No one will ever come and fill up the glass; only we can do that ourselves.

Yet, it was the consequences for the city and the local population of the ineffective recovery process, rather than its causes, that were of greater concern to respondents. For many, the lack of reconstruction represented the failure to rebuild not only the physical but also the social fabric of the city. Reference was frequently made to L'Aquila becoming a ghost-town, a modern-day Pompeii, though some recognised a distinction:

There are differences, because Pompeii is a dead city. L'Aquila is a dead city inasmuch as you are looking at ruined houses, but not the inhabitants. There are still people who live there who, like me, live close by and cannot wait to return. 
Nevertheless, it was the lifelessness of the city, particularly its historical centre, that was referred to most frequently in the interviews and that was summarised eloquently by one respondent when discussing the influx of tourists following the earthquake:

I noticed instantly... the presence of tourists had not been evident before in my city. They came to see the rubble, but not only the rubble. Because what emerges is silence. And it's not the silence of a normal night, but the silence of a lack life; there is a silence within the shadows of the sunset that conveys the sense that there exists a real absence of life.

Others described the city centre as a museum, 'a museum where people can walk around, around the houses, and see the objects, furniture, stuff that still remains in the same place since that night, that is the museum'. But it is not a museum in the traditional sense of the word; it is evidence of the physical destruction of the city, but not of the social consequences of the disaster. In other words, initially at least there were no focal points amongst the destruction that could symbolise the human tragedy, no places where the human story of the earthquake could be told, contemplated or understood. Yet, as has long been recognised (Foote, 2003), communities that are struck by disasters often seek to commemorate the victims and pay tribute to their sacrifice, whether at actual places of death, at burial sites or in public spaces more generally. Not only does the process of planning, creating and establishing such memorials assist a community in coming to terms with a disaster, but the memorials then become the focus of individual and collective loss and a symbol of a community working towards common and collective goals. As one respondent suggested:

So physical memorials are important if people are to remember what has happened, not just to the city, but to each and every individual with their particular experiences.

They also become, of course, an attraction to be visited by tourists.

Not surprisingly, perhaps, given both the slow disaster recovery process and the lack of any formal attempt on the part of city authorities to establish memorials (or, indeed, any tourism infrastructure, such as signage, to facilitate the disaster tourism experience), the local community created a number of memorials not only to commemorate those who perished in the earthquake but also to communicate with visitors. Such memorials include: photographs of the eight students who lost their lives and a poem in their memory on the fence 
surrounding the ruined student house; a large collection of the house keys of destroyed houses attached to some fencing; banners, posters and signs attached to buildings around the city; a growing collection on the windows of a disused café of 'post-it' notes written by local people and visitors which included the word 'Amarcord' ('I remember' in northern Italian dialect); and, large photographs displayed in the city centre which, taken by a local photographer, were a powerful interpretation of the human cost of the earthquake.

From observations during the research, it was evident that these memorials had become tourist attractions and, specifically, a focus for disaster tourist visits to the city. A number of respondents, for example, reported that tourists had asked them for directions to the student house. As discussed shortly, they were also instrumental in transforming both the behaviour of tourists and the local community's perceptions of them although in addition, some signs explicitly sought to modify tourists' attitudes and behaviour. For example, one such sign (translated) reads:

\section{For tourists, foreigners and the curious}

What you are visiting is not just a random place; it is NOT a tourist attraction.

This was a part of our city which, until 16 months ago, was still alive.

It is too early to treat it like an archeological site,

And to stand smiling and to have a photograph taken.

Have pity for whoever died under the rubble and for the people who are still crying for that loss.

Consider that what you are looking at with curiosity is where we live.

Ours is a difficult reality that you will find difficult to understand.

The only help that you can give us is to tell with honesty what you saw, in order to make people aware of our dignity and strength to help us move forward and reconstruct

$$
\text { L'Aquila. }
$$

Thus, the interviews revealed that, for the local community, not only was the actual earthquake individually and collectively a transformative experience but also the subsequent sense of being 'forgotten' by the outside world on the one hand pointed to the need to draw on the traditional resilience of L'Aquilan society but, on the other hand, underpinned the community's need to seek the support and understanding of others.

\section{Local community perceptions of disaster tourism}


With regards to their perceptions of and responses to disaster tourism or, more precisely, the presence and behaviour of tourists coming to L'Aquila to gaze on the aftermath of the earthquake, respondents were first asked to reflect on their attitudes more generally to their city becoming a disaster tourism attraction or, more precisely, being developed and promoted as such. Two clear themes emerged. First, it became evident that not only did the local community have little or no experience of adopting the role of 'hosts' to tourists but also the city had long failed to exploit its potential as a tourist destination more generally. Although tourist facilities existed and were utilised prior to the earthquake, there was no 'strong, organised tourism'. As one respondent, a local tourism professional, lamented:

The reality is, like always, we have many resources available to us, but we are not able to develop and use them in any manner or form for tourism; and it is our own fault, the fault of our mentality, our culture.

In other words, although tourists had used L'Aquila as a base for visiting the area and, in particular, for mountain-based activities, the city itself had no tradition as a tourist destination in its own right, perhaps reflecting the parochial, closed character of L'Aquilan society discussed earlier.

Second, many of the respondents were strongly opposed to the concept of positively promoting disaster tourism in L'Aquila. One, for example, suggested it would simply be illogical to do so: 'This is one of the most beautiful, natural and historical areas of central Italy. Before the earthquake we didn't publicise ourselves, so why now?' For other respondents, even three years after the earthquake their priority was to work towards rebuilding their lives:

I think that, right now, our lives are already full of problems, logistical problems, things that other people don't even consider. People might think of the earthquake, the tragedy, the death ... but it's all the 'after' that is difficult. The principle objective is to regain a life, I won't say normal but a little calmer. Therefore, to think of this type of tourism, to think of something of this sort, if it is to happen then it will have to be much later. 
For the majority of respondents, however, developing disaster tourism was considered to be an invasion of their privacy, an intrusion into their grief and suffering, the exploitation of their community's disaster. As one respondent put it:

As for people who lost loved ones, I am not sure but probably the majority wouldn't be interested [in tourism]. The pain is too strong; why would they go about selling this pain?

Nevertheless, as discussed earlier, following the earthquake L'Aquila did become a disaster tourism destination, the media at the time reporting that tourists visited the ruined city in significant numbers during the summer of 2009 and beyond. Thus, the local community, along with the ruins of their city, unwillingly became a tourist attraction, the implicitly unwelcome object of the disaster tourists' gaze. Not surprisingly, therefore, when questioned about the tourists who visited L'Aquila following the earthquake, many respondents expressed negative attitudes. For some, it was the very presence of tourists intruding on their privacy and grief and, perhaps viewing them dispassionately, that they found upsetting:

Initially, this city became a place of catastrophe tourism. It was the biggest earthquake in Italy, even in Europe... It was seen as something sensational, which attracted people to come and see the mess, the rubble, the camps, a bit like a museum, like an exhibition. And in the initial stages it bothered me, it really bothered me, this catastrophe tourism.

Others were more explicit in expressing their negative perceptions, likening themselves to exhibits in a museum or animals in a zoo. As one respondent put it, 'I had the sensation of being viewed like an animal, as if someone was coming to inspect and examine me, like I was being spied on' whilst another stated: 'It's similar to people going to the zoo to see all the animals. One can feel very violated'.

However, two particular themes emerged within the local community's negative perceptions. First, many referred to the behaviour of tourists, specifically their lack of respect as demonstrated by taking photographs:

I cannot put up with these people, when I see them walking around the city, in front of houses which have collapsed to rubble, where friends of mine and other 
people I know lost their lives, taking photos... I would like to go over and break their cameras.

I want to stop them... They make me angry, angry, angry, because one should not photograph the pain of others. Because what do you do then? Go home, have a look through the photos, and what do you see? You don't see the pain.

Second, some respondents believed that tourists had come to L'Aquila not to try to understand the impacts of the disaster on the local community, to share their suffering, but simply to gaze on (and photograph) the destruction with, perhaps, an element of schadenfreude:

If they have come here just out of curiosity, and they think "at least this happened to them and not us", then this annoys me, it makes me angry.

Ifelt frustrated, because this morbid attachment towards such events shocked me. I don't find it as very appealing, especially considering how much suffering there was.

Nevertheless, it should be noted that not all respondents held or expressed such negative perceptions of disaster tourists / tourism in L'Aquila. In other words, the research revealed a variety of perceptions of or responses to disaster tourists on the part of respondents, from anger and antagonism, through ambivalence to positive support for tourism even in the initial period following the earthquake. For example, whereas some expressed anger: ' $I$ was extremely angry, particularly because people were coming and taking photos, capturing a tragic moment in time, a time that for us used to be our lives', others were more accepting of tourists: 'Fortunately tourists come and visit, at least they are moving round the city, it needs people, otherwise it will remain silent.' Indeed, for some, tourism was a positive phenomenon:

I am not sorry, it does not bother me. I would like the entire world to come for a little visit. I feel it is important; those people who do come begin to understand it a little, even if they have not lived it. 
We know these tourists are attracted by the tragedy, that they come and stare because they are curious. However, I do not mind these people coming... The tourists who come and take photos, what they do is continue to give L'Aquila a voice.

Moreover, of particular significance, the research revealed an overall softening over time of the local community's perceptions of or attitudes towards disaster tourism. That is, during the interviews, many respondents suggested that, as the months and years passed after the earthquake, their perceptions of tourists became more positive. Feelings of annoyance or antagonism towards tourists came to be replaced by recognition of the potential contribution of tourism to the recovery process both in terms being able to share their disaster, to explain their experiences with visitors - helping tourists to understand the earthquake being a cathartic process for local people - and also as a means of communicating to the outside world the continuing problems the city is facing. For example, one respondent stated:

Now people want to come and visit L'Aquila to see for themselves the truth and reality of this city and the state it is in, and to see what the media doesn't portray as the truth. It's perfectly fine with me... now I am beginning to realise the benefits, after three years, now that everyone in the world has forgotten about us...

Similarly, according to another respondent:

Even after two or three years, the people who come here couldn't believe the state of L'Aquila. People would say "seriously, this is what is happening here, we didn't realise, we didn't know that you were still living in these conditions". Therefore, I saw the positive sides of this type of tourism.

It was also suggested by some that the behaviour of tourists themselves changed over time. That is, it was evident from the interviews that, rather than simply gazing at and taking photographs of the ruins (and of themselves in front of the ruins), tourists began to engage more with the city, seeking out the memorials and talking with local people who themselves wanted to talk with tourists. One respondent admitted that: 
To be honest, if I happened to meet tourists, I would try to help them, to explain what they were looking at, to explain to them what there was before and to help them understand what they were gazing upon.

Another summarised the transformation in the behavior of tourists as follows:

There is more participation on the part of the people who come here. Of course, it's not as if they can offer anything, but they begin to understand... and the fact that they begin to understand helps you to feel less lonely.

Undoubtedly, the local community's increasingly positive perceptions of tourism and tourists reflected the situation the city and its population continues to find itself in although, as was considered in some interviews, the increasing length of time since the actual earthquake was also influential in both the transformation in their responses to tourism and, indeed, the behaviour and attitude of tourists. That is, as the disaster - the human cost of the earthquake receded in time, other factors came to determine the local community's perceptions of tourism.

\section{Discussion and conclusions}

As established in the introduction, the purpose of this paper was to explore the local community's perceptions of and responses to disaster tourism in L'Aquila following the earthquake that devastated the city in April 2009. In so doing, it sought not only to enhance knowledge and understanding of this particular manifestation of what is more broadly referred to as dark tourism from the perspective of the local community, but also to contribute to the debate surrounding research into resident / local community perceptions of tourism more generally.

Addressing the latter point first, recent criticisms of the resident perceptions research discussed in this paper point to a number of limitations, particularly the typical dependence on quantitative studies that are not located in the wider social context of the destination community. In adopting a qualitative approach that explored that wider context, this research was able to reveal a variety of factors that undoubtedly influenced and offered an explanation of the local community's perceptions of disaster tourism. In particular, the geographic isolation of the city and, perhaps, consequential parochial and closed character of L'Aquilan society arguably predetermined the community's largely negative attitude towards disaster 
tourists as well as suggesting why the city had, in the past, demonstrated little appetite for exploiting its cultural resources for tourism more generally. Equally, the individual and collective experiences of the earthquake discussed extensively in the interviews confirmed an inevitable though intuitive finding, that disaster tourism represented for most respondents an unwelcome intrusion into the community's tragedy and grief. Moreover, while the circumstances surrounding the lengthy and limited recovery process in L'Aquila are in all likelihood unique, understanding the causes and, in particular, the local community's response to these circumstances further contextualises their perceptions of tourism. Hence, this research reveals the value of adopting a broader, qualitative approach focusing on unpacking more of, if not 'the whole truth' (Moufakkir \& Reisinger, 2013, p. xiii) of the destination's social reality in resident perception research more generally.

Although this study was not longitudinal, the methodology also enabled an exploration of the local community's perceptions of disaster tourism in their city over time. That is, respondents were given the opportunity to reflect if and how their perceptions of tourism had changed over the three years since earthquake. Consequently, one of the most significant findings of this research was not only that the local community's perceptions of tourism did indeed transform over time, thereby, addressing a further criticism of the resident perception research more generally, but also that the direction of that transformation was from negative to positive. In other words, the interviews in this research pointed to the dynamism of the local community's perceptions of disaster tourism whilst, at the same time, challenging the traditional assumption based on early linear models (Butler, 1980; Doxey, 1975 ) that destination residents become increasingly dissatisfied with or antagonistic towards tourism over time.

Of course, it is not possible to draw direct comparisons between the outcomes of this research and these early models of resident responses to tourism, not least because disaster tourism destinations differ both analytically and in practice from the development of 'typical' tourist destinations. Nevertheless, two points demand emphasis. First, the transformation in perceptions revealed in this research is defined temporally, tourism being viewed more favourably as the disaster becomes temporally more distant, but is also related to the behaviour of tourists. That is, the transformation in the local community's perception of tourism is related directly to their interaction with tourists and the ways in which tourists 'consume' L'Aquila as a disaster tourism destination; as tourists engaged more proactively, seeking to understand the disaster more fully, local resident became more appreciative of their presence. And second, the transformation in the local community's perceptions is 
evidence of tourism's potential contribution to the recovery process. In other words, the local community's more positive response to tourism reflects their recognition of the benefits of tourism as a means of emotionally 'sharing' the disaster and communicating their continuing plight to the outside world.

This research, then, highlights the importance of identifying and understanding the local community's perceptions of and responses to tourism in disaster destinations. It also points to a number of practical implications. First, when easily accessible, as in the case of L'Aquila, disaster sites inevitably attract tourists. Moreover, in the immediate aftermath of a disaster, the local community is likely to resent the presence of those 'disaster tourists'. Thus, particularly in locations where earthquakes, hurricanes and other potentially disastrous natural events may be reasonably predicted, disaster recovery planning should include provisions to manage that inevitable influx of tourists. Depending on the nature of the disaster, this should focus on preventing or limiting access of tourists to the disaster site, not least to avoid local residents becoming resentful of their voyeuristic gaze. At the same, however, this research has suggested that through understanding its causes, that resentment may be mitigated by the effective management of tourists. Thus, a second implication is that appropriate behaviour on the part of tourists, their understanding of the disaster and their compassion for the victims should be encouraged by a variety of means, such as establishing official focal points or memorials for tourists to seek out, providing them with signage, information or guided tours, and by helping them to engage with the place and the community rather than gazing passively at the destruction. Indeed, this research suggests that tourists are responsive to such encouragement and facilitation; though apparently passive 'gazers' when left to wander haphazardly, tourists in L'Aquila readily engaged with the social dimension of the disaster when provided with the 'tools' to do so. Moreover, the shift in the local community's perception of disaster tourists suggests that such visitor management is not only imperative but is key to highlighting a potential benefit of such tourism; that is, its contribution to the recovery process. And third, the experience of L'Aquila in terms of the recovery process, though perhaps extreme, reveals an important facet of disaster tourism. That is, the impacts of a disaster continue long after the media lose interest. Thus, tourism may be an effective means of continuing to highlight the plight of a disaster area when it is no longer headline news.

Of course, all disasters are unique and, hence, the outcomes of this research are particular to the case of L'Aquila. Nevertheless, it suggests that future research would be beneficial in deepening understanding of disaster tourism, not least in L'Aquila itself where 
further research might identify transformations both in the nature of tourism to the city and local residents' perceptions of it, the extent to which tourism has contributed to the recovery process and, in particular, if wider knowledge of the problems facing city has encouraged support for the reconstruction of L'Aquila. In addition, similar research at other disaster sites might reveal both common and unique characteristics of disaster tourism and local residents' responses to it.

Generally, however, disasters such as the earthquake in L'Aquila are life changing events for those who endure them: as one respondent in this research put it: 'I went to bed as a 17 year old girl, and awoke a completely different person'. Irrespective of the context, therefore, understanding the relationship between the local community and those who come to gaze on their disaster may contribute over time to tourism becoming a factor in the recovery process.

\section{References}

Alexander, D. (2010). The L'Aquila earthquake of 6 April 2008 and Italian government policy on disaster response. Journal of Natural Resources Policy Research, 2(4), 325342.

Andereck, K., \& Nyaupane, G. (2011). Exploring the nature of tourism and quality of life perceptions among residents. Journal of Travel Research, 50(3), 248-260.

Andriotis, K., \& Vaughan, R. (2003). Urban residents' attitudes toward tourism development: The case of Crete. Journal of Travel Research, 42(2), 172-185.

Ap. J. (1990). Residents' perceptions research on the social impacts of tourism. Annals of Tourism Research, 17(4), 610-616.

Barkun, M. (1974). Disaster and the millennium. New Haven, Conn.: Yale University Press.

Biran, A., \& Hyde, K. (2013). Editorial: New perspectives on dark tourism. International Journal of Culture, Tourism and Hospitality Research, 7(3), 191-198.

Blom, T. (2000). Morbid tourism: A postmodern market niche with an example from Althorp. Norwegian Journal of Geography, 54(1), 29-36.

Bowman, M., \& Pezzullo, P. (2009). What's so 'dark' about 'dark tourism'? Death, tourism and performance. Tourist Studies, 9(3), 187-202. 
Butler, R. (1980) The concept of a tourism area cycle of evolution. Canadian Geographer, 24(1), 5-12.

Coats, A., \& Ferguson, S. (2013). Rubbernecking or rejuvenation: Post-earthquake perceptions and the implications for business practice in a dark tourism context. Journal of Research for Consumers, 23(1), 32-65.

Cohen, E. H. (2011). Educational dark tourism at an in populo site: The Holocaust Museum in Jerusalem. Annals of Tourism Research, 38(1), 193-209.

Deery, M., Jago, L., \& Fredline, L. (2012). Rethinking social impacts of tourism research: A new research agenda. Tourism Management, 33(1), 64-73.

Di Nicola, P. (2011). L'Aquila: i numeri della vergogna (the numbers of shame). Available at: http://espresso.repubblica.it/dettaglio/laquila-i-numeri-della-vergogna/2148633/25. Accessed: 10/04/2011

Dinmore, G. (2013). Italy: lost in stagnation. Financial Times. http://www.ft.com/cms/s/0/e7f43eac-a775-11e2-bfcd00144feabdc0.html\#axzz3U5XODjh0. Accessed 11.03.15

Doxey, G. (1975). A causation theory of visitor-resident irritants: Methodology and research inferences. Proceedings of the Sixth Annual Conference of the Travel Research Association (pp. 195-198). San Diego, CA: Travel and Tourism Research Association.

Faulkner, B. (2001). Towards a framework for tourism disaster management. Tourism Management, 22(2), 135-147.

Faulkner, B., \& Tideswell, C. (1997). A framework for monitoring community impacts of tourism. Journal of Sustainable Tourism, 5(1), 3-28.

Flamminio, C. (2009). Tourism over the rubble of the earthquake in L'Aquila. Available at: http://www.demotix.com/photo/tourism-over-rubbles-earthquake-laquila124762, Accessed: 13/10/2011.

Foote, K. (2003). Shadowed ground: America's landscapes of violence and tragedy. Austin: University of Texas Press.

Fritz, C. (1961). Disasters. In R. Merton \& R. Nisbet (Eds.), Contemporary social problems (pp. 651-694). New York: Harcourt.

Kreps, G. (1998). Disaster as systemic event and social catalyst. In E. Quarantelli (Ed.), What is a disaster? (pp. 31-55). New York: Routledge.

Gillham, B. (2005). Research interviewing: The range of techniques. Maidenhead: McGrawHill Education. 
Gould, K., \& Lewis, Y. (2007). Viewing the wreckage: Eco-disaster tourism in the wake of Katrina. Societies Without Borders, 2(2), 175-197.

Harrill, R. (2004). Residents' attitudes toward tourism development: A literature review with implications for tourism planning. Journal of Planning Literature, 18(3), 251-266.

Huh, C., \& Vogt, C. (2008). Changes in residents' attitudes toward tourism over time: A cohort analytical approach. Journal of Travel Research, 46(4), 446-455.

InAbruzzo (2009). Il terremoto diventa attrattore turitico. Available at: http://www.inabruzzo.com/?p=10646. Accessed: 14/10/2011.

Jurowski, C., \& Gursoy, D. (2004). Distance effects on residents' attitudes toward tourism. Annals of Tourism Research, 31(2), 296-312.

Kim, K., Uysal, M., \& Sirgy, J. (2013). How does tourism in a community impact the quality of life of community residents? Tourism Management, 36, 527-540.

King, N., \& Horrocks, C. (2010). Interviews in qualitative research. London: Sage.

Kreps, G. (1995). Disasters as systemic event and social catalyst: A clarification of the subject matter. International Journal of Mass Emergencies and Disasters, 13(3), 255284.

Logan, W. \& Reeves, K. (Eds) (2008). Places of pain and shame: Dealing with 'difficult heritage'. Abingdon: Routledge.

McGehee, N., \& Anderek, K. (2004). Factors predicting rural residents' support for tourism. Journal of Travel Research, 43(2), 131-140.

Moufakkir, O., \& Reisinger, Y. (2013). Introduction: Gazemaking: Le regard. Do you hear me? In O. Moufakkir \& Y. Reisinger (Eds.) The host gaze in global tourism (pp. xixvi). Wallingford: CABI.

Muzaini, H., Teo, P., \& Yeoh, B. (2007). Intimations of postmodernity in dark tourism: The fate of history at Fort Siloso, Singapore. Journal of Tourism and Cultural Change, $5(1), 28-45$.

Nunkoo, R., Smith, S., \& Ramkissoon, M. (2013). Resident attitudes to tourism: A longitudinal study of 140 articles from 1984 to 2010. Journal of Sustainable Tourism, 2l(1), 5-25.

Pearce, P., Moscardo, G., \& Ross, G. (1996) Tourism community relationships. Oxford: Pergamon Press.

Pérez, E., \& Nadal, J. (2005). Host community perceptions: A cluster analysis. Annals of Tourism Research, 32(4), 925-941. 
Pforr, C., \& Hosie, P. (2007). Crisis management in tourism : Preparing for recovery. Journal of Travel and Tourism Marketing, 23(2-4), 249-264.

Quarantelli, E. (1985). What is disaster? The need for clarification in definition and conceptualization in research. In B. Sowder (Ed.) Disasters and mental health: selected contemporary perspectives (pp. 41-73). Washington, D.C.: US Government Printing Office.

Raine, R. (2013). A dark tourist spectrum. International Journal of Culture, Tourism and Hospitality Research, 7(3), 242-256.

Rojek, C. (1993). Ways of escape. Basingstoke: MacMillan.

Rojek, C. (1997). Indexing, dragging and the social construction of tourist sites. In C. Rojek \& J. Urry (Eds.), Touring cultures: Transformations of travel and theory (pp. 52-74). London: Routledge.

Rossi, A., Menna, C., Asprone, D., Jalayer, F., \& Manfredi, G. (2012). Socio-economic resilience of the L'Aquila community in the aftermath of the 2009 earthquake. Proceedings of the $15^{\text {th }}$ World Conference on Earthquake Engineering, Lisbon. http://www.iitk.ac.in/nicee/wcee/article/WCEE2012_2225.pdf

Sandiford, P., \& Seymour, D. (2007). A discussion of qualitative data analysis in hospitality research with examples from an ethnography of English public houses. Hospitality Management 26(3), 724-742.

Santana, G. (2003). Crisis management and tourism: Beyond the rhetoric. Journal of Travel and Tourism Marketing, 15(4), 299-321.

Seaton, A. (1996). Guided by the dark: from thanatopsis to thanatourism. International Journal of Heritage Studies, 2(4), 234-244.

Sharpley, R. (2014). Host perceptions of tourism: A review of the research. Tourism Management, 42(1), 37-49

Sharpley, R., \& Stone, P. (2009). The darker side of travel: The theory and practice of dark tourism. Bristol: Channel View Publications.

Smith, K. (1995). Environmental hazards: Assessing risk and reducing disaster. London: Routledge.

Stone, P. (2006). A dark tourism spectrum. Towards a typology of death and macabre related tourist sites, attractions and exhibitions. Tourism: An Interdisciplinary International Journal, 54(2), 145-160.

Stone, P. (2012). Dark tourism and significant other death: Towards a model of mortality mediation. Annals of Tourism Research, 39(3), 1565-1587. 
Stone, P. (2013). Dark tourism scholarship: A critical review. International Journal of Culture, Tourism and Hospitality Research, 7(3), 307-318.

Tarlow, P. (2005). Dark tourism: The appealing side 'dark' side of tourism and more. In M. Novelli (Ed.), Niche Tourism: Contemporary Issues, Trends and Cases (pp. 47-57). Oxford: Elsevier.

Tunbridge, J., \& Ashworth, G. (1996). Dissonant heritage: Managing the past as a resource in conflict. Chichester: John Wiley.

Tierney, K., Lindell, M., \& Perry, R. (2001). Facing the unexpected: Disaster preparedness and response in the United States. Washington, D.C.: Joseph Henry Press

Twigg, J. (2004). Disaster risk reduction: Mitigation and preparedness in development and emergency programming. Good Practice Review No. 9. London: Overseas Development Institute.

UNISDR (2009). Terminology in disaster risk reduction. Geneva: United Nations International Strategy for Disaster Reduction.

Vargas-Sánchez, A., Plaza-Mejía, M., \& Porras-Bueno, N. (2009). Understanding residents' attitudes toward the development of industrial tourism in a former mining community. Journal of Travel Research, 47(3), 373-387.

von Vacano, M., \& and Zaumseil, M. (2013). Understanding disasters: An analysis and overview of the field of disaster research and management. In M. Zaumseil, S. Schwartz, M von Vacano, G. Sullivan \& J. Prawitasari-Hadiyono (Eds.), Cultural psychology of coping with disasters: The case of an earthquake in Java, Indonesia (pp. 3-44). New York: Springer-Verlag.

Westover, P. (2012). Necromanticism: Travelling to meet the dead, 1750-1860. Basingstoke: Palgrave Macmillan.

White, L., \& Frew, E. (Eds.) (2013). Dark tourism and place identity: Managing and interpreting dark places. Abingdon: Routledge.

Williams, E. (2009). L'Aquila earthquake tragedy has united Italy. Available at: http://www.telegraph.co.uk/expat/5163570/LAquila-earthquake-tragedy-has-unitedItaly.html. Accessed: 22/12/2009.

Woosnam, K. (2012). Using emotional solidarity to explain residents' attitudes about tourism and tourism development. Journal of Travel Research, 51(3), 315-327. 